\title{
Characterization of ultrafine particles generated in charcoal street grills in the city of Armenia (Colombia). Case study
}

\section{Caracterización de partículas ultrafinas generadas en alimentos asados en parrillas al carbón en Armenia (Colombia). Caso de estudio}

\author{
Milena E. Gómez ; Rafael Humberto Villamizar²; Lázaro V. Cremades ${ }^{3}$.
}

\begin{abstract}
${ }^{1}$ Chemist, Esp. Ph.D. Universidad del Quindío, Faculty of Health Sciences, Occupational Safety and Health Program. Armenia - Quindío, Colombia; e-mail: milenagomez@uniquindio.edu.co; Dhttps://orcid.org/0000-0002-6257-8305

${ }^{2}$ Chemilcal engineer, M.Sc. Universidad del Quindío, Faculty of Health Sciences, Occupational Safety and Health Program. Armenia - Quindío, Colombia; e-mail: rhvillamizar@uniquindio.edu.co; Dhttps://orcid.org/0000-0001-6959-0086
\end{abstract}

${ }^{3}$ Ph.D. Universitat Politècnica de Catalunya, Departament d'Enginyeria de Projectes i de la Construcció, ETSElB. Barcelona, Spain; e-mail: lazaro.cremades@ upc.edu; Dhttps://orcid.org/0000-0003-0600-8188

*corresponding author: lazaro.cremades@upc.edu

How to cite: Gómez, M.E.; Villamizar, R.H.; Cremades, L.V. 2020. Characterization of ultrafine particles generated in charcoal street grills in the city of Armenia (Colombia). Case study. Rev. U.D.C.A Act. \& Div. Cient. 23(2):e1555. http://doi.org/10.31910/rudca.v23. n2.2020.1555

Open access article published by Revista U.D.C.A Actualidad \& Divulgación Científica, under Creative Commons License CC BY-NC 4.0

Official publication of the Universidad de Ciencias Aplicadas y Ambientales U.D.C.A, University, Accredited as a High-Quality Institution by the Colombian Ministry of Education.

Received: May 16, 2020 Accepted: October 5, 2020 Edited by: Ingeborg Zenner de Polanía

\section{INTRODUCTION}

Nowadays the use of charcoal grills for food cooking is very common in the world, due to the organoleptic characteristics in taste and texture which the food receives and which make it appealing to the consumer. In 2014, around 53 million tons of charcoal were produced worldwide (Vicent et al. 2018). Charcoal is a cheap fuel with low sulfur and mercury contents, very common in restaurants and food grills. The use of firewood, pieces of dry wood, is also common, which when burned produces charcoal and gives a flavor characteristic of grilled food, highly appreciated by consumers.

The smoke from wood that does not burn completely contains several chemicals including carbon monoxide (CO). More than 150 people die each year from $\mathrm{CO}$ poisoning related to the use of domestic heating appliances. CO is odorless and colorless. Therefore, it is highly recommended to install a CO detector if a wood-burning stove or fireplace is used (EPA, 2018).

As for $\mathrm{CO}_{2}$ emissions, a charcoal barbecue generates $6.7 \mathrm{~kg}$ of $\mathrm{CO}_{2}$ per day, which is equal to that produced by a vehicle driven $35 \mathrm{~km}, 2.9$ times higher than that generated by LPG (Liquefied Petroleum Gas) (Vicent et al. 2018). Besides, particulate emissions from barbecues are considered likely to be carcinogenic to human health, in addition to the fact that grill workers experience chronic exposure to $\mathrm{CO}$ (Wilson et al. 2011). 
Chicken, veal, and fish roasts generate large quantities of polycyclic aromatic hydrocarbons (PAH), such as benzopyrenes, benzene, toluene, methylene chloride joined in the smoke particles of grills. $\mathrm{PAH}$ are considered dangerous to health. Higher concentrations of PAH have been measured, in this order, in chicken $>$ fish $>$ meat or veal. As for heavy metals, traces of $\mathrm{V}, \mathrm{Cr}, \mathrm{Mn}, \mathrm{Fe}, \mathrm{Co}, \mathrm{Ni}, \mathrm{Cu}$, $\mathrm{Zn}, \mathrm{As}$, and $\mathrm{Se}$ are also detected. Traces of $\mathrm{Fe}>\mathrm{Pb}>\mathrm{Cu}>\mathrm{Mn}$ were detected in the roasts of chicken and meat (Iqbal \& Kim, 2016; Inobeme et al. 2018; Vicent et al. 2018).

Research works about emissions from grills found high levels of $\mathrm{PM}_{10}$ and $\mathrm{PM}_{2.5}$ in the air from Asian barbecue-type restaurants (Lee et al. 2001; Lee et al. 2011).

In Colombia, it is very common to find informal street grills selling charcoal-roasted foods such as "arepas" (corn tortillas), meats, bananas and corn. This informal economy represents the livelihood of many families. In these stalls, workers are exposed for 5 to 9 hours a day to particulate matter emitted from their grills. This paper presents a characterization of ultrafine particles, also called $\mathrm{PM}_{2.5}$ (less than $2.5 \mu \mathrm{m}$ in diameter) from some charcoal street grills in the city of Armenia (Colombia), in order to determine whether their workers are at risk to their health. These particles are considered hazardous to respiratory health due to their high deposition capacity in the alveolar region (Määtä et al. 2006).

Traditionally, particle characterization was limited to the determination of mass concentration. The reason for choosing mass as a basic measurement parameter is to be found in its relative independence from the instrument used and in the ease with which it can be determined (García et al. 2006). In the characterization of particulate matter, it is recommended to consider the properties of particles that influence human health, the shape of the particle, and the equivalent aerodynamic diameter (Harper et al. 2002; Harper et al. 2004). The determination of the properties provides a fairly complete characterization of the particles. Irregularity in the shape of particles is decisive for filtration processes, as it is often related to the formation of agglomerates, which are more easily retained by mouth and nose (Harper et al. 2004).

Most of the physical properties of a particle system are established as statistical values of the geometric properties of particles, dimension (size and distribution), shape, and surface characteristics (specific area and porosity), density, morphology, the mass concentration of particles, number and chemical composition of particles (Harper et al. 2004).

In the case of wood smoke, the greatest threat from smoke comes from ultrafine particles or $\mathrm{PM}_{2.5}$. These microscopic particles can enter the eyes or respiratory system, and cause burning eyes, runny nose, and diseases such as bronchitis. Fine particles can worsen asthma symptoms and trigger asthma attacks. Fine particles can also trigger heart attacks, irregular heart rhythms, and heart failure, especially in people who are already at risk for these diseases (EPA, 2018).
In the mid-1990s, the International Organization for Standardization (ISO), the European Committee for Standardization (CEN), and the American Conference of Governmental Industrial Hygienists (ACGIH) agreed on definitions of inhalable, thoracic, and respirable particles that penetrate and/or deposit in various compartments of the human respiratory tract. The inhalable fraction is equivalent to the amount of dangerous particles that will enter the nose and/or mouth. The amount of particles that enter the respiratory system beyond the larynx is the thoracic fraction. The amount deposited in the gas exchange region of the lungs is the respirable fraction (Lidén \& Harper, 2006).

\section{MATERIAL AND METHODS}

A qualitative and quantitative observational descriptive study of the properties of ultrafine particles (UP) of the collected environmental samples was carried out. For the sampling of UP, the analytical method NIOSH 0600 "Respirable Particles" was followed (NIOSH, 1994).

A total of two different samples were taken in two street charcoal grills at the city of Armenia (Colombia): One sample from an arepa grill (G1) and another sample from a meat and potato grill (G2). Samples were taken at a working day from 12:00 to 14:00, considered peak hours due to the volume of people eating at these sites.

In order to characterize the particles in a wide range of sizes, a GilAir5 Gilian Multi Fol. No. 800519 air sampler pump with Sensidyne Filian Gilibrator TM 2 803024B, Bubble Generator Rang 20 CC-6LPM P7N 800286, and a 37mm PVC filter were used.

For the analysis of the particle distribution, an image scanning was carried out in the electron microscopy laboratory of the University of Caldas in Colombia. Microphotographs (three-dimensional and high-resolution images) were taken for the observation and characterization of organic and inorganic materials (morphological differentiation, phase identification, particle dispersion) in a nanometric scale. The elemental chemical analysis and its distribution on the surface was carried out by means of an EDAX probe based on energy dispersive spectroscopy (EDS).

Descriptive statistics were used to analyze the results. Descriptive statistics establish the main particle characteristics from observation and counting. Mean, median, and mode are the most commonly used expressions of defining the center of a distribution (Wonnacott \& Wonnacott, 1997). The Stat Graphics ${ }^{\circledR}$ program was used to calculate the statistical functions.

\section{RESULTS AND DISCUSSION}

The concentrations of particles in the samples obtained with the analytical method NIOSH 0600 can be seen in table 1 .

The microphotographs obtained by electron microscopy when examining the filters that retain the particles during the sampling of 
arepas (G1) and meat and potatoes (G2) grills can be seen in figure 1. Ultrafine particles, with agglomerated characteristics typical of nanoparticles, can be observed. These shapes and sizes make the particles breathable, allowing the contaminant to penetrate into the lower respiratory tract (LRT) (Lidén \& Harper, 2006).

It was not possible to determine the number of UP collected due to their trend to agglomerate. All the particles taken in the photographs have non-uniform shapes; square, spherical, and rectangular particles can be distinguished.

Chemical analysis of the G1 filter sample gave $95.9 \%$ carbon and $4.1 \%$ oxygen, characteristic elements of carbohydrates (corn flour).
As these particles accumulate in LRT, they can generate COPD or chronic pulmonary emphysema. On the other hand, in the analysis of the G2 filter sample, the presence of zinc was observed in $0.08 \mathrm{wt} \%$, which is an element usually present in meat; nitrogen $(14.5 \mathrm{wt} \%)$ of proteins; carbon $(74.5 \mathrm{wt} \%)$, and oxygen $(10.7 \mathrm{wt} \%)$, typical of carbohydrates and fats. Traces of aluminum were also observed, which probably came from the material of the grills, made of an alloy of iron and aluminum.

A descriptive statistical analysis was applied to the microphotographs obtained by joining the two samples of the two grills. The results are shown in table 1.

Table 1. Sample concentrations according to NIOSH analytical method 0600 and descriptive statistical analysis of grouped samples.

\begin{tabular}{|l|c|}
\hline \multicolumn{1}{|c|}{ Site } & $\begin{array}{c}\text { Average occupational } \\
\text { concentration }\end{array}$ \\
\hline Grill 1 of arepas (corn tortillas) & $3.08 \mathrm{mg} / \mathrm{m}^{3}$ \\
\hline Grill 2 of meat and potatoes & $7.79 \mathrm{mg} / \mathrm{m}^{3}$ \\
\hline Statistical variable & Value $(\mathrm{nm})$ \\
\hline Average & 370.05 \\
\hline Typical error & 29.04 \\
\hline Median & 508.90 \\
\hline Mode & 254.50 \\
\hline Standard deviation & 215.37 \\
\hline Variance & 45542.42 \\
\hline Geometric mean & 301.60 \\
\hline
\end{tabular}

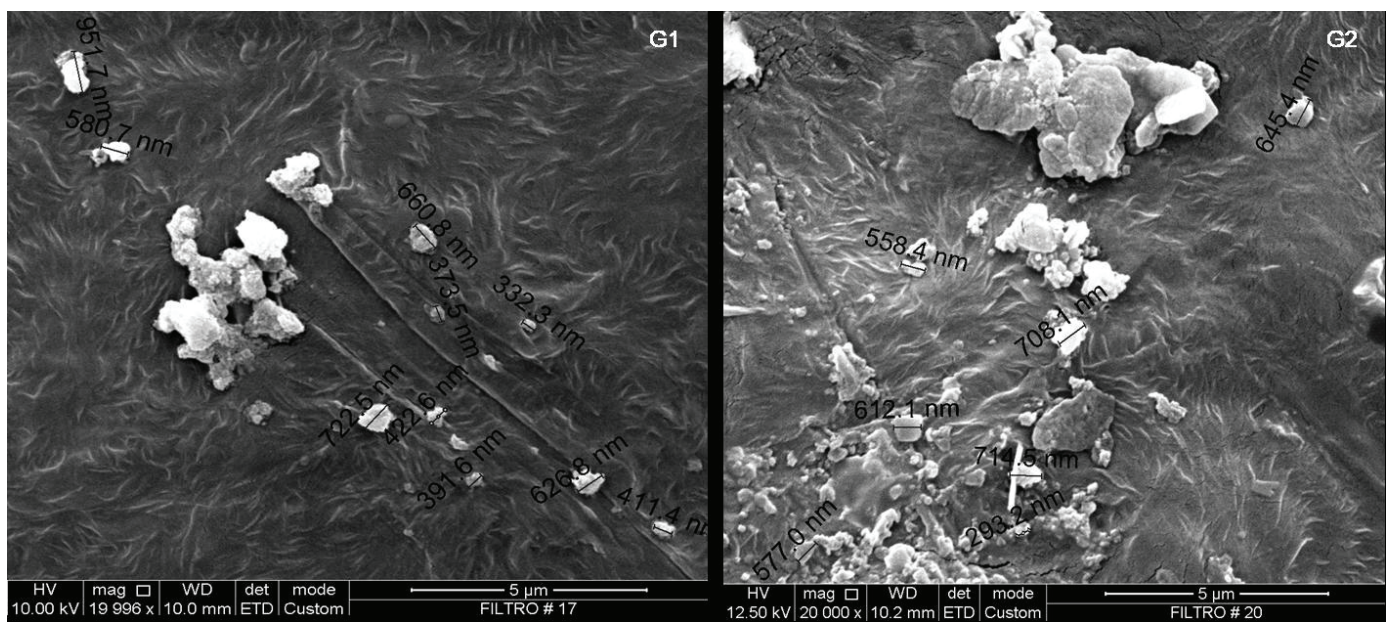

Figure 1. Microphotographies of the filters obtained in the arepa grill (G1) and the meat and potato grill (G2). 
The presence of UP is observed. These particles can enter to the LRT, directly to the blood stream, and may have negative shortterm effects on people's health, such as ischemia, genotoxicity, oxidation of proteins, oxidative stress, damage to cell membranes, COPD, among others (OMS, 1989; Määtä et al. 2006; Lucas-Ramos et al. 2008).

In conclusion, as for the prevention of occupational risks, it is important to train workers who perform their tasks in the sites studied in healthy lifestyles, in the permanent use of respiratory protection elements and to carry out once a year, epidemiological surveillance that will allow them to prevent respiratory problems or diseases and preserve their quality of life. Although it is difficult for the informal sector of the economy the installation of extraction hoods, if advisable to install them in restaurants that are dedicated to charcoal roasts.

In the study area of the city of Armenia, none of these informal workers is associated with the social security system, especially the Health and Labor Risks system. Moreover, there activity contributes to air pollution. All of this is part of a social problem, that the Colombian government has tried to address by creating worker protection strategies and implementing norms that in some way contribute to the protection of workers and the environment. It is for this reason that this study was carried out, to reveal the dangers to which these people are subjected due to the uncontrolled exposure of ultrafine particles generated by the grills. Indeed, these workers, on days longer than 8 hours, seven days a week, are offering a product in great demand by consumers, but their health is very likely to be harmed.

Conflicts of interest: The manuscript was prepared and revised by all authors, who declare the absence of any conflict which can put the validity of the presented results at risk. Financial support: This study was financed by the University of Quindío through the Project No. 867.

\section{REFERENCES}

1. EPA. 2018. El humo de leña y la salud. U.S. Environmental Protection Agency. Retrieved from https://espanol.epa.gov/espanol/el-humo-de-la-lena-y-susalud. Accessed: October 10, 2019. [In Spanish].

2. GARCÍA, F.F.; AGUDELO, R.A.; JIMÉNEZ, K.M. 2006. Distribución espacial y temporal de la concentración de material partículado en Santa Marta, Colombia. Rev. Facultad Nacional de Salud Pública. 24(2):73-82.

3. HARPER, M.; AKBAR, M.Z.; ANDREW, M.E. 2004. Comparison of wood dust aerosol size distributions collected by air samplers. J. Environ. Monit., 6:18-22.

https://doi.org/10.1039/b312883k
4. HARPER, M.; MULLER, B.S.; BARTOLUCCI, A.L. 2002. Determining particle size distributions in the inhalable size range for wood dust collected by air samplers. J. Environ. Monit. 4:642-647. https://doi.org/10.1039/B202856p

5. INOBEME, A.; AJAI, A.I.; MANN, A.; IYAKA, Y.A. 2018. Determination of polycyclic aromatic hydrocarbons and heavy metal contents of barbecue beef, fish and chicken. Food and Environ. Safety J. 17(4):395-403. Available at: http:/ / fia-old.usv.ro/fiajournal/index.php/FENS/article/ view/615. (Accessed 26/09/2020).

6. IQBAL, M.A.; KIM, K.H. 2016. Sampling, pretreatment and analysis of particulate matter and trace metals emitted through charcoal combustion in cooking activities. Trends in Analytical Chem. 76:52-59.

https://doi.org/10.1016/j.trac.2015.11.005

7. LEE, J.B.; KIM, K.H.; KIM, H.J.; CHO, S.J.; JUNG, K.; KIM, S.D. 2011. Emission rate of particulate matter and its removal efficiency by precipitators in under-fired charbroiling restaurants. Sci. World J. 11:1077-1088. https://doi.org/10.1100/tsw.2011.103

8. LEE, S.C.; LI, W.M.; YIN CHAN, L. 2001. Indoor air quality at restaurants with different styles of cooking in metropolitan Hong Kong. Sci. Total Environ. 279:181-193. https://doi.org/10.1016/s0048-9697(01)00765-3

9. LIDÉN, G.; HARPER, M. 2006. The need for an international sampling convention for inhalable dust in calm air. J. Occup. and Environ. Hygiene, 3(10):D94-D101. https://doi.org/10.1080/15459620600920580

10. LUCAS-RAMOS, P.; IZQUIERDO-ALONSO, J.L.; RODRÍGUEZ-GONZÁLEZ, J.M.; BELLÓN-CANO, J.M.; ANCOCHEA-BERMÚDEZ, J.; CALLE-RUBIO, M.; CALVO-CORBELLA, E.; MOLINA-PARÍS, J.; PÉREZRODRIGUEZ, E.; PONS, S. 2008. Asociación de factores de riesgo cardiovascular y EPOC. Resultados de un estudio epidemiológico (estudio ARCE). Archivos de Bronconeumología. 238(5):233-238. https://doi.org/10.1157/13119937

11. MÄÄTÄ, J.; LEHTO, M.; LEINO, M.; TILLANDER, S.; HAAPAKOSKI, R.; MAJURI, M.L.; WOLF, H.; RAUTIO, S.; WELLING, I.; HUSGAFVEL, K.; SAVOLAINEN, K.; ALENIUS, H. 2006. Mechanisms of particle-induced pulmonary inflammation in a mouse model: exposure to wood dust. Tox. Sci. 93(1):96-104. https://doi.org/10.1093/toxsci/kfl026 
12. NIOSH. 1994. Particulates not otherwise regulated, respirable. Manual of Analytical Methods 0600. Fourth edition. National Institute for Occupational Safety and Health.

13. OMS. 1989. Epidemiología de las enfermedades y accidentes relacionados con el trabajo. Décimo informe del Comité Mixto OIT/OMS sobre Higiene del Trabajo, Organización Mundial de la Salud (OMS), ISBN 0509-2507. Ginebra. 84p.

14. VICENT, E.D.; VICENT, A.; EVTYUGINA, M.; CARVALHO, R.; TARELHO, I.A.C.; ADUBER, F.I.; ALVES, C. 2018. Particulate and gaseous emission from charcoal combustion in barbecue grills. Fuel Processing Tech. 176:296-306.

https://doi.org/10.1016/j.fuproc.2018.03.004
15. WILSON, N.; PARRY, R.; JALALI, J.; JALALI, R.; MCLEAN, L.; MCKAY, O. 2011. High air pollution levels in some takeaway food outlets and barbeque restaurants. Pilot study in Wellington city, New Zealand. The New Zealand Medical J. 124(1330):81-97.

16. WONNACOTT, T.H.W.; WONNACOTT, R.J.W. 1997. Introducción a la Estadística. Limusa Noriega Editores, México. 788p. [In Spanish]. 